Henoma I. B., полковник, начальник відділу розробки та впровадження військової символіки Збройних Сил України

\title{
ІСТОРИЧНІ ВИТОКИ ТА РОЗВИТОК СИМВОЛІКИ ВІЙСЬКОВОЇ СЛУЖБИ ПРАВОПОРЯДКУ У ЗБРОЙНИХ СИЛАХ УКРАЇНИ
}

\begin{abstract}
Анотація. Мета дослідження полягає у висвітленні генези та впровадження символіки Військової служби правопорядку у Збройних Силах України. Методи. Вибір дослідницьких підходів до розкриття мети визначив застосування принципів системності та комплексності, методу структурного аналізу, а також семантичного та історико-хронологічного методів. Використання вказаних методів дослідження сприяло отриманню власних результатів, що мають значення для історичної науки. Наукова новизна одержаних результатів полягає в постановці і розробленні актуальної теми генези символіки Військової служби правопорядку у Збройних Силах України в новітній період української державності, яка в науковому вимірі отримала недостатнє висвітлення. Сучасні суспільно-політичні та воєнні виклики не лише не послабили роль та значення символів, a, навпаки, посилили його, загостривши увагу на принципі означення державної приналежності військового формування та принципі ідейної відповідності змісту символів ідеалам, які відстоюються у збройній боротьбі. Неабиякої актуальності набуває питання пошуку історичних витоків української військової символіки та її розвитку в незалежній Україні, оскільки аналіз історичних підвалин, змісту символіки дозволить вийти на якісно новий рівень знань $з$ історії культури, фалеристики, вексилології, уніформістики, геральдики та інших спеціальних історичних дисциплін. Відтворення основних процесів використання символіки сприятиме реконструкції історії становлення та історичного розвитку військової символіки України, утвердженню символіки Збройних Сил України та з'ясуванню ступеня впливу символіки на духовну культуру Українського народу.

Результати осмислення сутності процесу розроблення символіки Військової служби правопорядку у Збройних Силах України можуть слугувати важливою складовою частиною в дослідженні сучасних проблем військового будівництва та розвитку військово-історичної науки, а також дослідження предметного поля військової символіки України. Висновки. Історичний процес становлення української державності виявив об'єктивну необхідність створення власних державних збройних військових формувань. Символічне позначення українського війська та інших силових оборонного сектору та сектору безпеки є складовою частиною державної політики України. Підкреслено, що символіка Військової служби правопорядку носить комплексних характер, відображає історичні традиції та новітню воєнну історію i $є$ складовою частиною символіки Збройних Сил України, що функціонує в контексті розвитку державної символіки.

Ключові слова: символіка, геральдика, фалеристика, уніформістика, вексилологія, Україна, Військова служба правопорядку, Збройні Сили України, прапор, нарукавна емблема, штандарт, символ.
\end{abstract}

Постановка проблеми. Військова символіка України вже давно стала предметом наукового дослідження, бо має власну досить багату історію та традиції. У широкому розумінні символіка є умовним відображенням подій, явищ, понять, ідей через конкретні властиві їм вияви - символи. Символіка вивчає історію походження, функціонування й використання різновидів символів, що $€$ концентрованою формою відбиття і фіксації наукових, релігійних та інших знань людини за допомогою стилізованого зображення [2, с. 4].

Практика показує, що сучасні суспільно-політичні та воєнні виклики не лише не послабили роль та значення символів, a, навпаки, посилили його, загостривши увагу на принципі означення державної приналежності військового формування та принципі ідейної відповідності змісту символів ідеалам, які відстоюються у збройній боротьбі.

Творення військової символіки незалежної України відбувалося в часи складного процесу державного та військового будівництва. За основу під час опрацювання символіки військових формувань бралися класичні закони геральдики та інших спеціальних історичних дисциплін, кращі зразки минулого, що відповідали давньому корінню Українського народу. Новітня історія України лише доводить важливість військових атрибутів у мобілізації населення до збройного захисту держави [3, c. 8-9].

Неабиякої актуальності набуває питання пошуку історичних витоків української військової символіки та їі розвитку в незалежній Україні, оскільки аналіз історичних підвалин, змісту символіки дозволить вийти на якісно новий рівень знань з історії культури, фалеристики, вексилології, уніформістики, геральдики та інших спеціальних історичних дисциплін. Відтворення основних процесів використання символіки сприятиме реконструкції історії становлення та історичного розвитку військової символіки України, утвердженню символіки Збройних Сил України та з'ясуванню ступеня впливу символіки на духовну культуру Українського народу.

Історичні аспекти становлення та розвитку військової символіки України, зокрема й символіки військової жандармерії українських державних утворень періоду національно-визвольної боротьби 1917-1921 рр., висвітлені в дослідженнях В. Карпова, Д. Табачника [4], А. Руккаса [9], О. Гавриленка, М. Литвина, О. Ярмиша [1], О. Муравйова [7], спогадах I. Козака [5] та А. Чаборика [20]. Питанням становлення та розвитку символіки Військової служби правопорядку у Збройних Силах України присвячені публікації М. Хорошунова [12-15] та Ю. Шаповала [19]. Джерельну базу становлять документи, 
що зберігаються в державних архівах. Зокрема, фонди Центрального державного архіву вищих органів влади та управління України містять важливі документи з історії розроблення та впровадження символіки Армії Української Народної Республіки та Української Галицької Армії, в тому числі й такі, що стосуються безпосередньо формувань військової жандармерії. Однак зазначимо, що ця тема потребує подальшого комплексного і всебічного дослідження.

Отже, актуальність дослідження зумовлена динамікою процесу становлення та розвитку української школи символіки на сучасному етапі, що потребує подальшого всебічного розгляду історичних витоків та виникнення та еволюції символіки Військової служби правопорядку у ЗС України.

Виклад основного матеріалу. Перші формування військової поліції (жандармерії) в українській армії були створені в період національно-визвольної боротьби 1917-1921 pp. Польова жандармерія (з червня 1919 р. - Польова сторожа) при Галицькій Армії була започаткована у грудні 1918 р. Очолив іiі сотник Іван Козак. Через запланований наступ на Львів тоді був створений відділ Польової жандармерії при Команді «Групи Південь», перейменованої потім на 7-му Львівську бригаду. Такий же відділ сформували при Начальній Команді Галицької Армії. Згодом аналогічні відділи створювалися при командах корпусів та бригад.

Польова жандармерія відносилась до так званих помічних формацій і займалась питаннями безпеки військ та підтримання належного порядку в місцевостях їх дислокації [6, c. 528]. Головними завданнями Польової жандармерії були: збереження ладу і спокою в місцях перебування й руху військ, збір і охорона військового майна, особливо зброї та набоїв; попередження диверсійних акцій на залізничних шляхах, мостах та лініях зв'язку; протидія дезертирству; супроводження конвоїв і кур'єрів тощо. Іноді вони виконували також обов'язки Державної жандармерії (боротьба зі шпигунством, саботажем і ворожою пропагандою) там, де іiі підрозділів не було.

Підрозділи Польової жандармерії підлягали Начальній Команді Галицької Армії, крім того, стосовно виконання військово-поліцейських функцій вони підпорядковувалися начальникам штабів військових з'єднань, у розташуванні яких дислокувалися.

Польова жандармерія не мала власного однострою (уніформи), вона користувалася уніформою військового зразку із зубчаткою та отоком на кашкеті вишневого кольору. Службовою відзнакою усіх військовослужбовців Польової жандармерії була жовто-блакитна опаска на лівому рукаві [10].

Навесні 1920 року за допомоги польських союзників відбувалось відродження регулярної Армії Української Народної Республіки. Важливе місце у цьому процесі відводилось створенню військових органів правопорядку «для забезпечення спокою і ладу на терені УНР, а також для переведення відповідних екзекутивних заходів щодо організації Української Армії», зокрема частин Польової жандармерії, що мали слідкувати за порядком та забезпечувати належний рівень дисципліни серед військовослужбовців. 14 березня постановою українського уряду № 163 було засновано Корпус військових жандармів, який поділявся на польову (для служби на фронті) і запільну (для служби в тилу) жандармерії. За наказом С. Петлюри від 15 березня 1920 року безпосередня організація військової жандармерії була покладена на військового міністра полков- ника В. Сальського [18, арк. 1]. У Кам'янці-Подільському був створений спеціальний навчальний центр - польовий жандармський курінь, який мав готувати майбутніх жандармів. Надалі 3 його випускників планувалося формувати підрозділи спочатку польової, а потім і запільної жандармерії [9, с. 67].

Наказом Головної управи військ УНР № 57 від 3 травня 1920 р. було затверджено зразок уніформи для української польової жандармерії: «1. Відзнаки: ранги - загальновійськові; петлиці - кольору білого і по діагоналі національного прапору стежка; на погонах число куреня і літери «П.Ж.»; аксельбанти для всіх рангів (на лівому боці) світло-блакитного кольору; для старшин повний аксельбант, а для козаків скорочений. На лівому рукаві державний герб захисного кольору; 2. Кашкет: тулія і денце - білі; околиш - синій; кокарда - загальновійськова і по козирку білий джгут; 3. Френч і шаровари загального зразка, кольору синього» [17, арк. 62]. Невдовзі на прохання командира учбового куреня польової жандармеpiї підполковника М. Панкіїва колір нарукавного тризуба змінили із захисного на білий, що було закріплено наказом ГУВ № 182 від 22 липня [16, арк. 80].

Цікаві відомості про уніформу знаходимо у спогадах М. Чаборика, який у 1920 році в ранзі підхорунжого служив в українській жандармерії. За його словами, спочатку всі ходили в різних одностроях: російських гімнастьорках, російських і австрійських шинелях, цивільних куртках. Перший формений одяг було видано наприкінці травня, після візиту до учбового куреня С. Петлюри. Із цього приводу М. Чаборик згадував: «Ми одержали новенькі й гарні однострої. Це були англійські убрання, з доброго сукна табачково-зеленкуватого кольору, такі ж самі шапки із червоною обвідкою і тризубом, черевики і гамаші, а дехто і чоботи. ... Для прикраси ми одержали також білі плетені шнури, які носилися на блузі, білі вилоги на комірі та золоті паски і зірки для означення наших ранг. I тоді варто було подивитися: це була дійсна краса і гордість УНР!» [20, с.12]. Як бачимо, описаний М. Чабориком однострій у цілому відповідає тому мундиру, що запроваджувався наказом ГУВ № 57, за виключенням хіба що кашкетів із червоними обвідками й тризубами. Очевидно, невдовзі головні убори було приведено у відповідність до затвердженого зразка, підтвердженням чого можуть слугувати тогочасні оригінальні фотографії українських жандармів, на яких ті носять кашкети з білою тулією [9, с. 68].

У 2002 р. відповідно до вимог Закону України «Про військову службу правопорядку у Збройних Силах України» й наказу Міністра Оборони України «Про заходи щодо створення Військової служби правопорядку у Збройних Силах України» від 12 червня 2002 року № 198 на базі відповідних структурних підрозділів Збройних Сил України було завершено формування Військової служби правопорядку (ВСП). У зв'язку з формуванням нової структури Збройних Сил України постала потреба в опрацюванні їі символіки. 27 березня 2003 р. на засіданні Комісії з державних нагород та геральдики було прийнято схвальне рішення щодо емблеми, нарукавних і нагрудних знаків розрізнення військовослужбовців ВСП. Наказом Міністра оборони України від 12 травня 2003 р. № 131 затверджено емблеми Військової служби правопорядку, нарукавного знака, емблеми на комір і погони військовослужбовців ВСП, нагрудного знака військовослужбовців Головного управління ВСП, базового зразка нагрудного знака військовослужбовців 
Центрального управління ВСП в місті Києві і Київській області та територіальних управлінь ВСП, службового нагрудного знака військовослужбовців Патрульно-постової служби ВСП, службового нагрудного знака військовослужбовців Військової інспекції безпеки дорожнього руху ВСП, а також опис нарукавної пов'язки військовослужбовців ВСП [19].

Емблема Військової служби правопорядку у Збройних Силах України являла собою вписану в коло багатопроменеву зірку білого металу з 8 великими, а між ними - 24 малими променями. У центрі зірки - овальний медальйон синього кольору iз зображенням лекторського пучка із двосічною сокирою (фасція), накладеного на два схрещені мечі вістрям униз. Медальйон має два пружки, між якими на малиновому тлі напис: «Військова служба правопорядку». Усі зображення, пружки медальйона, напис - жовтого кольору.

Нарукавний знак військовослужбовців ВСП - круг діаметром 75 мм, полинового кольору, у центрі якого розміщено емблему ВСП. Кант нарукавного знака жовтого кольору. Емблема на комір і погони військовослужбовців ВСП - восьмикутна зірка золотого кольору з розбіжними двогранними променями, накладена на вінок з дубового листя.

Нагрудний знак військовослужбовців ВСП - виготовлена з білого металу овальна багатопроменева зірка 38 великими, а між ними - 24 малими променями. У центрі зірки - чотирикутний щит, покритий емаллю синього кольору з подвійними пружками жовтого металу, накладений на два схрещені мечі вістрям униз. У щиті - зображення прямого рівностороннього хреста 3 розбіжними кінцями малинового кольору й пружками золотого кольору, посередині вміщено зображення Знака Княжої Держави Володимира Великого. Між пружками щита напис: «Військова служба правопорядку» на малиновому емалевому тлі. Зображення мечів і написи жовтого металу. Розмір нагрудного знака: висота - 65 мм, ширина - 55 мм.

Нагрудний знак військовослужбовців Центрального управління ВСП у місті Києву і Київській області та територіальних управлінь ВСП має такий самий вигляд і розміри, як і загальний нагрудний знак військовослужбовців ВСП, за винятком того, що в щиті замість хреста із Тризубом - зображення герба міста, у якому розташоване управління регіонального підрозділу [19].

Службові нагрудні знаки військовослужбовців Патрульно-постової служби і Військової інспекції безпеки дорожнього руху ВСП своїм виглядом і матеріалом відповідають загальному знаку військовослужбовців ВСП, лише під хрестом у першого вміщено напис «ППС», у другого - «ВІБДР», а в підніжжі щита обох знаків - стрічка 3 вигравіюваним п'ятизначним номером чорного кольору. Діаметр знаків 70 мм.

У літописі Військової служби правопорядку є три пам'ятних нагрудних знаки - до 5-ї, 10-ї та 15-ї річниць. Розроблення перших двох знаків здійснював відповідний структурний підрозділ Генерального штабу ЗС України - Відділ військової символіки та геральдики - на прохання Головного управління ВСП.

Пам’ятний нагрудний знак «10 років Військовій службі правопорядку у Збройних Силах України» (далі - нагрудний знак) був затверджений Начальником Генерального штабу - Головнокомандувачем 3бройних Сил України генерал-полковником Г. Педченком 18 липня 2011 р. Виготовлений із жовтого металу i має форму кола діаметром 32 мм. На лицьовому боці нагрудного знака зображено вертикально розташований лікторський пучок із двосічною сокирою, який оточують дві лаврові гілки. На тлі лікторського пучка розміщено щит, покритий напівпрозорою емаллю синього кольору. На щиті зображено емблему Збройних Сил України. Сторони хреста емблеми Збройних Сил України покрито напівпрозорою емаллю малинового кольору, медальйон - емаллю синього кольору. Нижче зображено фігурну стрічку, що перевиває лікторський пучок і частково накладається на лаврові гілки. На стрічці напис: «ЧЕСТЬ I ЗАКОН» [14].

На зворотному боці нагрудного знака в центрі зображено емблему військовослужбовців Військової служби правопорядку у Збройних Силах України на комір чи погони. По колу розміщено напис «ВІЙСЬКОВА СЛУЖБА ПРАВОПОРЯДКУ» (зверху) та «2002-2012» (знизу). По колу нагрудний знак обрамлено бортиком. Усі зображення та написи рельєфні.

За допомогою вушка та кільця нагрудний знак сполучається 3 прямокутною колодкою жовтого металу, обтягнутою стрічкою. Колодка має розмір: висота - 42 мм, ширина - 28 мм. На зворотному боці колодки міститься застібка для прикріплення нагрудного знака до одягу. Стрічка нагрудного знаку муарова 3 повздовжніми смужками: білого кольору шириною 5 мм, малинового - 3 мм, синього - 3 мм, жовтого - 2 мм, синього 2 мм, жовтого - 2 мм, синього - 3 мм, малинового - 3 мм, білого шириною 5 мм. Планка нагрудного знака являє собою металеву пластинку, обтягнуту відповідною стрічкою. Розмір планки: висота - 12 мм, ширина - 28 мм.

Щодо елементів, зображених на нагрудному знаку, то лікторський пучок із сокирою - стародавній символ влади та порядку. Зображення лікторського пучка із двосічною сокирою є на емблемі Військової служби правопорядку у Збройних Силах України, затвердженій наказом Міністра оборони України. Лаврові гілки символізують славу, а щит уособлює захист Військовою службою правопорядку життя, здоров'я, прав та законних інтересів військовослужбовців та працівників Збройних Сил України. У свою чергу, емблема Збройних Сил України вказує на належність Військової служби правопорядку до Збройних Сил України. Напис «Честь і закон»девіз Служби правопорядку. Напис «Військова служба правопорядку» відображає назву служби, а роки означають рік створення Служби правопорядку та рік святкування 10-ї річниці. Емблема на комір чи погони є елементом символіки Служби правопорядку. Білий, малиновий, синій та жовтий кольори стрічки відображають кольори Служби правопорядку [14].

У 2016 р., усвідомлюючи, що чергова річниця Служби правопорядку може відбутись без традиційного нагородження, керівництво ВСП вирішило самостійно розробити знак, який логічно продовжив би лінійку попередніх пам'ятних нагрудних знаків. Для цього, вивчивши архіви, віднайшли нереалізований варіант малюнка пам'ятного нагрудного знака, розробленого Відділом військової символіки та геральдики у 2011 р. напередодні 10-ї річниці ВСП. Тоді на розгляд керівництва Служби правопорядку було запропоновано два варіанти, один із яких був схвалений.

Доопрацювавши малюнок нагрудного знака, керівництво ВСП вирішило офіційно його затвердити. Для цього підготували відповідні документи та встановленим порядком подали їх на підпис. Як результат, 13 квітня 2017 р. побачив світ наказ Генерального штабу ЗС України № 131, який затверджував 
Положення про почесний нагрудний знак «15 років Військовій службі правопорядку у Збройних Силах України», його опис та малюнок. Наказ підписав начальник Генерального штабу - Головнокомандувач 3С України генерал армії України В. Муженко.

Згідно з описом нагрудний знак виготовлений із білого металу і має форму кола діаметром 32 мм. На лицьовому боці зображено емблему ВСП та розміщено написи по колу «ЧЕСТЬ I ЗАКОН» (зверху) та «2002-2017» (знизу). Зворотний бік не має зображень та написів. По колу нагрудний знак обрамлений бортиком. За допомогою вушка та кільця нагрудний знак сполучається 3 прямокутною колодкою білого металу, обтягнутою стрічкою. Розмір колодки: висота - 42 мм, ширина - 28 мм. На зворотному боці колодки - застібка для прикріплення нагрудного знака до одягу. Стрічка нагрудного знака у цілому повторює стрічки пам'ятних нагрудних знаків, розроблених до 5-ї та 10-ї річниць ВСП. Різниця полягає лише в кількості жовтих смужок. Так, стрічка пам'ятного нагрудного знака, розробленого у 2007 р., мала по центру одну жовту смужку. Разом із білими, синіми та малиновими смужками це уособлювало кольори емблеми ВСП. У 2012 р. жовтих смужок було вже дві, кожна символізувала по 5 років Служби. Відповідно, стрічку знака до третього ювілею, прикрашають три жовті смужки. Інші смужки (білі, малинові та сині) залишись без змін. Варто зазначити, що пояснювальної записки до наказу не додавалось, а Положення про знак повторювало положення до аналогічних нагрудних знаків [15, с. 11]. Пам'ятний нагрудний знак «15 років Військовій службі правопорядку у Збройних Силах України» був виготовлений тиражем 1200 шт. Загалом новий нагрудний знак військових правоохоронців гармонійно доповнив вже наявний комплекс військової символіки, що склався з моменту формування ВСП.

Наказом Міністра оборони України від 20 листопада 2017 р. № 606 «Про затвердження Правил носіння військової форми одягу та знаків розрізнення військовослужбовцями Збройних Сил України та ліцеїстами військових ліцеїв» були визначені, зокрема, емблема на комір, нарукавний знак, берет та беретний знак для військовослужбовців Військової служби правопорядку у Збройних Силах України.

На початку липня 2019 р. Начальником Генерального штабу - Головнокомандувачем ЗСУ був затверджений комплект нарукавних емблем для військових частин Військової служби правопорядку згідно з новою концепцією. Сам процес затвердження тривав понад рік. Розглядались кілька варіантів, які мали принципові відмінності щодо кольорового виконання. Зокрема затверджені нарукавні емблеми Головного управління, Центрального, Західного, Південного та Східного територіальних управлінь, навчального центру, дисциплінарного батальйону, а також центру спеціального призначення (протидії диверсіям та терактам).

Усі нарукавні емблеми мають вигляд червоного геральдичного щита, оздобленого срібним кантом. Центральним елементом емблеми Головного управління є стилізоване зображення срібної фасції, накладеної на схрещені між собою срібні пірнач та меч. Фасція є символом підтримання правопорядку, пірнач - символом органу військового управління, меч - символом готовності до захисту батьківщини.
Центральним елементом емблеми Центрального територіального управління $є$ стилізоване зображення схрещених між собою срібних фасції та куші. Куша $є$ елементом історичного герба Київських земель та символізує Північний регіон України.

Нарукавна емблема Західного територіального управління оздоблена стилізованим зображенням срібного лева, що пильнує, який опирається на срібну фасцію. Лев є символом Західного регіону України.

Геральдичний щит емблеми Південного територіального управління розділений в основі двома срібними хвилеподібними поясами. Центральним елементом є стилізоване зображення срібної висхідної фасції. Під фасцією розташоване стилізоване зображення срібного корабля. Корабель та хвилеподібні пояси символізують Південний регіон України.

У правому верхньому куті геральдичного щита Східного територіального управління розміщено срібне стилізоване зображення сонця, що сходить. Центральним елементом є стилізоване зображення срібної фасції, схиленої ліворуч. Сонце, що сходить, символізує Східний регіон України.

Центральним елементом нарукавної емблеми навчального центра є стилізоване зображення срібної фасції, накладеної на схрещені між собою срібні смолоскип та перо, які символізують навчальні підрозділи.

На емблемі дисциплінарного батальйону - стилізоване зображення срібної фасції, накладеної на схрещені між собою срібні ключі, які є символом безпеки та покірності.

На щиті емблеми центру спеціального призначення (протидії диверсіям та терактам) - стилізоване зображення срібного меча, розташованого скосом праворуч вістрям у лівий нижній край, що розтинає чорну двоголову змію. Меч, що розтинає двоголову змію, символізує протидію терористичним та розвідувально-диверсійним діям противника.

Висновки. Історичний процес становленя державності України виявив об'єктивну необхідність створення збройних військових формувань. Символічне позначення українського війська $є$ складовою частиною державної політики. Підкреслено, що символіка Військової служби правопорядку розвивалася в руслі процесу зародження та становлення символіки Збройних Сил України і є її складовою частиною.

\section{Jimepamypa:}

1. Гавриленко О.А., Литвин М.Р., Ярмиш О.Н. Жандармерія Західно-Української Народної Республіки. Енциклопедія історії України: Т. 3: Е-Й / Редкол.: В.А. Смолій (голова) та ін. НАН України. Інститут історії України. Київ : В-во «Наукова думка», 2005. 672 с.

2. Карпов В.В. Історичні витоки української військової символіки та iї розвиток в незалежній Україні : дис. док-ра іст. наук : 07.00 .01 історія України ; Переяслав-Хмельницький. 2015.

3. Карпов В.В. Українська звитяга у символах. Київ : Видавець Олег Філюк, 2016. 422 с.

4. Карпов В.В., Табачник Д.В. Військова символіка держави. Київ : Либідь, 2007. 264 с.

5. Козак І. Дещо про державну жандармерію ЗУНР. Украйнський скиталещь. 1923. № 16-17/18.

6. Крип'якевич І., Гнатевич Б., Стефанів 3. та ін. Історія українського війська (від княжих часів до 20-х років XX ст.). 4-е вид., змін. і доп. Львів : Світ, 1992.712 с.

7. Муравйов О. Головні символи нашого війська. Військово-історичний альманах. 2006. № 2. С. 139-148.

8. Однострої українських військових формацій 1914-1920 pp. URL : http://www.national.org.ua/library/odnostroi.html. 
9. Руккас А. Польова жандармерія Армії Української Народної Республіки у 1920 р. Вісник Київського національного університету імені Тараса Шевченка. Серія Історія. 2016. № 3(130) . С. 66-69.

10. Сідак В. Національні спецслужби в період Української революції 1917-1921 pр. (невідомі сторінки історії). § 5.1. Становлення спецслужб ЗУНР. Київ : Видавничий дім «Альтернативи», 1998. URL : http://exlibris.national.org.ua/sidak/index.html.

11. Старшини, генерали українських армій. Віртуальний музей УНР. URL : https://muzejunr.io.ua/album791111_15.

12. Хорошунов М. Беретний знак для військових правоохоронців. Знак. 2018. Ч. 74. С. 10-11.

13. Хорошунов М. Новий однострій - нові підходи. Знак. 2016. Ч. 70. С. 10.

14. Хорошунов М.Ю. Військова служба правопорядку. Київ : Ентерпрінт, 2014. 154 с.

15. Хорошунов М. Третя річниця ВСП з новим пам'ятним нагрудним знаком. Знак. 2017. Ч. 73. С. 11.

16. Центральний державний архів вищих органів влади та управління України (ЦДАВО України). Ф. 1075. Оп. 2. Спр. 4. Арк. 80.

17. ЦДАВО України. Ф. 1075. Оп. 2. Спр. 61. Арк. 62.

18. ЦДАВО України. Ф. 1078. Оп. 2. Спр. 91. Арк. 1.

19. Шаповал Ю.І. Символіка Військової служби правопорядку. Військово-історичний альманах. 2003. Ч. 2(7). С. 106-111.

20. Chaboryk M. Na shliakhakh vyzvolnoi borotby. Dorohovkaz. 1969. № 26(45). S. 9-12.

Nepota I. Historical origins and development of symbolism law enforcement service in the Armed Forces of Ukraine

Summary. The purpose of the study is to highlight the genesis and implementation of the symbolism of the Military Law Enforcement Service in the Armed Forces of Ukraine. Methods. The choice of research approaches to goal disclosure determined the application of the principles of systematicity and complexity, the method of structural analysis, as well as the semantic and historical-chronological method. The use of these methods of research contributed to obtaining their own results that are relevant to historical science. The scientific novelty of the obtained results is to formulate and develop a topical topic of the genesis of the symbolism of the Military Law Enforcement Service in the Armed Forces of Ukraine in the recent period of Ukrainian statehood, which has received insufficient coverage in the scientific dimension. Contemporary sociopolitical and military challenges have not only weakened the role and meaning of symbols, but rather reinforced it, focusing on the principle of defining the state of military affiliation and the principle of ideological conformity of the content of symbols to the ideals espoused in armed struggle. The question of finding the historical origins of Ukrainian military symbolics and its development in independent Ukraine becomes of great urgency, since the analysis of historical foundations, the content of symbolism will allow us to reach a new level of knowledge in the history of culture, phallistics, vexillology, uniforms, heraldry and other special historical disciplines. Reproduction of the basic processes of symbolic use will help to reconstruct the history of the formation and historical development of military symbols of Ukraine, to establish the symbolism of the Armed Forces of Ukraine and to clarify the degree of influence of symbolism on the spiritual culture of the Ukrainian people.

The results of understanding the essence of the process of developing the symbolism of the Military Law Enforcement Service in the Armed Forces of Ukraine can serve as an important component in the study of contemporary problems of military construction and development of military-historical science, as well as the study of the subject field of military symbolism of Ukraine. Conclusions. The historical process of becoming Ukrainian states revealed the objective need to create their own state armed military formations. The symbolic designation of the Ukrainian military and other security and security forces is an integral part of Ukraine's state policy. It is emphasized that the symbolism of the Military Law Enforcement Service is complex, reflects the historical traditions and the recent military history and is an integral part of the symbolism of the Armed Forces of Ukraine, which functions in the context of the development of state symbols.

Key words: symbolism, heraldry, phaleristics, uniforms, vexillology, Ukraine, Law Enforcement Service, Armed Forces of Ukraine, flag, sleeve emblem, standard, symbol. 